\title{
Faecal toxin and severity of antibiotic-associated pseudomembranous colitis
}

\author{
DW BURDON, RH GEORGE, * GAG MOGG, Y ARABI, H THOMPSON, \\ M JOHNSON, J ALEXANDER-WILLIAMS, MRB KEIGHLEY
}

From the General Hospital, Birmingham B4 6NH, and *the Children's Hospital, Birmingham B16 8ET

SUMMARY The relationship between faecal toxin titre, histological evidence of pseudomembrane in $\stackrel{+}{+}$ the rectum, and severity of antibiotic-associated colitis has been analysed from data on 62 patientser whose faeces contained Clostridium difficile toxin. There was a significant correlation between $\mathrm{a}^{\infty}$ toxin titre of 6400 or more and the presence of pseudomembrane $(p<0.05)$. There was no correlation $\cong$ between toxin titre, duration of diarrhoea, total white cell count, temperature, serum albumin or $\vec{z}$ serum orosomucoid concentrations. There was, however, a significant correlation between the presence of rectal pseudomembrane and duration of diarrhoea $(\mathrm{p}<0.005)$. Exposure to clindamycin $\vec{\oplus}$ or lincomycin was also associated with a significantly higher toxin titre than that seen in patients who were given other antibiotics. The duration of diarrhoea was not longer and rectal pseudomembrane did not occur more often in the patients who had received clindamycin or lincomycin.o

Clostridium difficile has been implicated as the aetiological agent responsible for antibiotic-associated pseudomembranous colitis (AAC). ${ }^{12}$ Most patients with histologically proven AAC have both $\mathrm{Cl}$ difficile and its toxin in their faeces, while the remaining patients have either $\mathrm{Cl}$ difficile or toxin. Faecal toxin and $\mathrm{Cl}$ difficile are also found in some patients with antibiotic-associated diarrhoea in whom sigmoidoscopic examination and rectal biopsy do not provide evidence of pseudomembrane. It is likely that some of these patients have patchy involvement of the intestine with sparing of the rectum, and that they constitute a group of patients with a mild form of AAC. ${ }^{3}$ The amount of toxin in faecal specimens can be estimated by titration. The purpose of this report is to describe the relation between the faecal toxin titre, the presence of rectal pseudomembrane, and the severity of illness in a group of patients with diarrhoea after antibiotic treatment.

\section{Patients and methods}

Cl difficile toxin was found in the faeces of 62 patients with antibiotic-associated diarrhoea between September 1977 and September 1979, and these patients form the subject of this report. Diarrhoea was defined as three or more bowel actions or $a \frac{\varpi}{\varnothing}$ colostomy output in excess of 1 litre daily. The toxin 2 titre was determined by serial twofold dilution of $\overrightarrow{0}$ faeces supernatant incubated with Hela cells. ${ }^{4}$ When 3 faecal toxin titres were estimated on more than one sample from the same patient, the highest value obtained was used in the analysis. However, when a correlation was made between toxin titre and the presence of rectal pseudomembrane, only patients 3 . with a titre estimated within 24 hours of a biopsy were included. For the purpose of analysis, patients were divided into a high titre group with a toxin titre $\mathrm{O}$ of 6400 or greater, and a low titre group with a toxin? titre of less than 6400. Pseudomembrane was identified by sigmoidoscopy, and in rectal biopsies according to the criteria of Price and Davies. 5 o Patients treated with vancomycin or metronidazole N were excluded from the analysis of duration of $N$ diarrhoea because of the effect of these antibiotics $\omega$ on the clinical course of AAC. ${ }^{7}$ The white cell count and temperature data were the highest values? recorded during the episode of AAC, and the serum albumin was the lowest value recorded. All clinical ${ }_{\square}$ and laboratory data were collected for various prospective studies on AAC, and not for this $\vec{\mathbb{}}$ purpose. Therefore a complete set of results was not $\frac{?}{\mathbb{Q}}$ available for some of the 62 patients. Student's $t$ test $\frac{\varrho}{\sigma}$ was used for statistical analysis, except for the relation between faecal toxin titre and the 
presence of pseudomembrane in which chi-square with Yates correction was used. Both statistical tests were used for the relation between faecal toxin titre and previous clindamycin or lincomycin treatment.

\section{Results}

The titres of faecal toxin varied from 50 to 640000 in the 62 patients, and showed a normal distribution. There were 26 patients with a titre greater than 6400 , 28 with a titre less than 6400 , and 8 with a titre of 6400 . The relation between the faecal toxin titre and the presence or absence of histologically confirmed rectal pseudomembrane in the 28 patients in whom these investigations were done within the same 24-hour period is shown in the Fig. In patients with pseudomembrane, the median titre was 16000 , compared
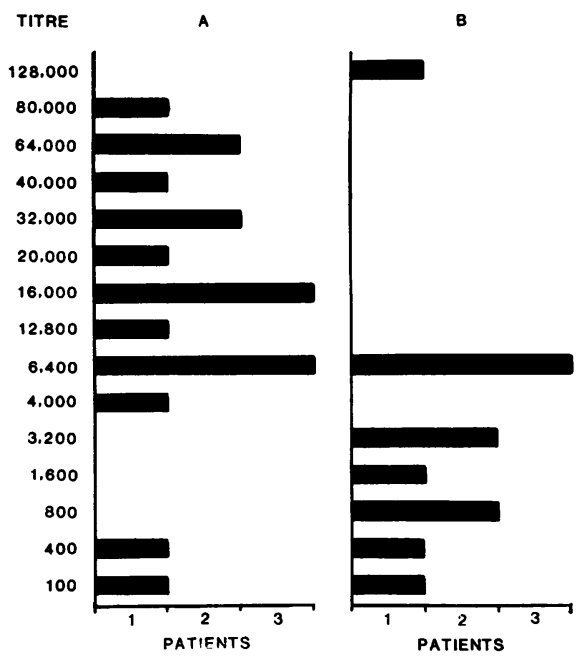

The relation between the faecal toxin titre and the presence of rectal pseudomembrane $(A)$, or the absence of pseudomembrane $(B)$.

with a median titre of 3200 in those without a pseudomembrane. There was a significant correlation between the presence of rectal pseudomembrane and a high toxin titre ( $\chi^{2}$ with Yates correction $=$ $4.31, \mathrm{p}<0.05$ ). The relation between the low or high titre groups and duration of diarrhoea, maximum white cell count, highest recorded temperature, orosomucoid level, and lowest albumin level are shown in Table 1. Only duration of diarrhoea and white cell count are increased in the high titre group, but these differences are not significant. Similar differences were observed when these indices were compared in patients with and without rectal pseudomembrane. However, the duration of diarrhoea was significantly longer in patients with a rectal pseudomembrane $(t$ test $\mathrm{p}<0.005)$ (Table 2 ).

Table 1 Relation between toxin titre and laboratory findings

\begin{tabular}{|c|c|c|}
\hline & \multicolumn{2}{|c|}{ Faecal toxin titre } \\
\hline & $\begin{array}{l}\text { Low titre } \\
<6400\end{array}$ & $\begin{array}{l}\text { High titre } \\
>6400\end{array}$ \\
\hline $\begin{array}{l}\text { Duration of diarrhoea (days) } \\
\text { Mean } \\
\text { Range }\end{array}$ & $\begin{array}{l}n=14 \\
9 \cdot 9 \\
2 \cdot 0-33 \cdot 0\end{array}$ & $\begin{array}{l}n=14 \\
15 \cdot 5 \\
2 \cdot 0-50 \cdot 0 \\
\text { NS }\end{array}$ \\
\hline $\begin{array}{l}\text { Total white cell count } \\
\left(\times 10^{\circ} / 1\right) \\
\text { Mean } \\
\text { Range }\end{array}$ & $\begin{array}{l}n=23 \\
13 \cdot 4 \\
7 \cdot 5-22 \cdot 4\end{array}$ & $\begin{array}{l}n=19 \\
17 \cdot 4 \\
7 \cdot 8-44 \cdot 4 \\
\text { NS }\end{array}$ \\
\hline $\begin{array}{l}\text { Sublingual temperature }\left({ }^{\circ} \mathrm{C}\right) \\
\text { Mean } \\
\text { Range }\end{array}$ & $\begin{array}{l}\mathrm{n}=12 \\
37 \cdot 7 \\
37 \cdot 0-39 \cdot 0\end{array}$ & $\begin{array}{l}\mathrm{n}=17 \\
37 \cdot 6 \\
37 \cdot 0-39 \cdot 0 \\
\mathrm{NS}\end{array}$ \\
\hline $\begin{array}{l}\text { Serum albumin }(g / l) \\
\text { Mean } \\
\text { Range }\end{array}$ & $\begin{array}{l}\mathrm{n}=12 \\
31 \cdot 7 \\
21 \cdot 0-47 \cdot 0\end{array}$ & $\begin{array}{l}\mathrm{n}=20 \\
32 \cdot 9 \\
21 \cdot 0-53 \cdot 0 \\
\text { NS }\end{array}$ \\
\hline $\begin{array}{l}\text { Serum orosomucoid }(\mathrm{g} / \mathrm{l}) \\
\text { Mean } \\
\text { Range }\end{array}$ & $\begin{array}{l}n=7 \\
2 \cdot 89 \\
1 \cdot 7-4 \cdot 15\end{array}$ & $\begin{array}{l}n=9 \\
2 \cdot 41 \\
0 \cdot 95-3 \cdot 6 \\
\text { NS }\end{array}$ \\
\hline
\end{tabular}

$\mathrm{n}=$ No. of patients. NS = not significant.

*Conversion: SI to traditional units-white cell count: $1 \times 10^{\circ} / 1 \approx$ $1000 / \mathrm{mm}^{3}$.

Table 2 Relation between duration of diarrhoea and presence or absence of rectal pseudomembrane

\begin{tabular}{lll}
\hline Duration (days) & \multicolumn{2}{l}{ Rectal pseudomembrane } \\
\cline { 2 - 3 } & Absent $(n=I 1)$ & Present $(n=14)$ \\
\hline Mean & $6 \cdot 3$ & $19 \cdot 2$ \\
Range & $3 \cdot 0-16.0$ & $5 \cdot 0-50 \cdot 0$ \\
Median & $6 \cdot 0$ & $16 \cdot 0$ \\
\hline
\end{tabular}

$\mathbf{n}=$ No. of patients.

In 32 patients, faecal toxin was identified after clindamycin or lincomycin treatment. The toxin titre in these patients was compared with that in 30 patients who had received other antibiotics before faecal toxin was identified (Table 3). A high toxin titre was present significantly more often in patients who had received clindamycin or lincomycin than in patients whose illness followed other antibiotics ( $\chi^{2}$ with Yates correction $\left.=4.9, \mathrm{p}<0.05\right)$. Comparison of the $\log _{10}$ titres in the two groups of patients also showed a significant difference $(t=2 \cdot 672$, $\mathrm{p}<0.01)$. There was no significant increase in the incidence of rectal pseudomembrane or in duration of diarrhoea in patients who had received clindamycin or lincomycin treatment (Table 3). 
Table 3 Comparison of patients who received clindamycin or lincomycin with patients treated with other antibiotics

\begin{tabular}{|c|c|c|}
\hline & $\begin{array}{l}\text { Clindamycin or } \\
\text { lincomycin } \\
(n=32)\end{array}$ & $\begin{array}{l}\text { Other antibiotics } \\
(n=30)\end{array}$ \\
\hline $\begin{array}{l}\text { Mean toxin titre } \\
\text { Range } \\
\text { Median }\end{array}$ & $\begin{array}{l}53700 \\
50-640000 \\
16000\end{array}$ & $\begin{array}{l}12700 \\
100-128000 \\
2400 \\
p<0.01\end{array}$ \\
\hline Patients with high toxin titre & 24 & 10 \\
\hline Patients with low toxin titre & 8 & $\begin{array}{l}20 \\
\mathrm{p}<0.05\end{array}$ \\
\hline $\begin{array}{l}\text { Patients with rectal } \\
\text { pseudomembrane } \\
\text { Patients with no rectal }\end{array}$ & 14 & 10 \\
\hline $\begin{array}{c}\text { pseudomembrane } \\
\text { Rectal biopsy not taken }\end{array}$ & $\begin{array}{l}9 \\
9\end{array}$ & $\begin{array}{l}7 \\
13 \\
\text { NS }\end{array}$ \\
\hline $\begin{array}{l}\text { Mean duration of diarrhoea } \\
\text { (days) in patients not treated } \\
\text { with vancomycin }\end{array}$ & $13 \cdot 2(n=14)$ & $\begin{array}{l}11 \cdot 5(n=13) \\
\text { NS }\end{array}$ \\
\hline
\end{tabular}

$\mathbf{n}=$ No. of patients. NS $=$ not significant.

\section{Discussion}

Sigmoidoscopy and rectal biopsy in patients with florid diarrhoea due to AAC may be technically difficult, and their diagnostic value is limited because the rectum is not affected by pseudomembrane in some patients. In contrast, the test for $\mathrm{Cl}$ difficile toxin in faeces is easily performed, and provides reliable diagnostic data. Measurement of the titre of faecal toxin is also relatively simple. It would be convenient if the level of the titre gave an indication of the severity of the disease, and assisted prognosis. Although there was a statistically significant correlation between a high toxin titre and the presence of pseudomembrane, this correlation was imperfect when judged in individual patients. It is necessary therefore to decide which of these two potential indices of disease severity is more reliable.

Prolonged diarrhoea is the most characteristic of the various clinical and laboratory findings in patients with AAC, and is therefore a potentially useful indicator of disease severity. The correlation between the presence of rectal pseudomembrane and an increased duration of diarrhoea suggests that identification of pseudomembrane may be of value in determining the prognosis. In contrast, the absence of any correlation between the toxin titre and duration of diarrhoea is not unexpected, because the latter is likely to be determined by the length of time in which toxin-producing $\mathrm{Cl}$ difficile inhabit the intestine.

Leucocytosis, pyrexia, hypoalbuminaemia, and raised serum orosomucoid concentrations have all been described in patients with AAC. ${ }^{8}$ The absence of any statistically significant difference in these $\stackrel{\overrightarrow{5}}{\overrightarrow{0}}$ parameters between patients with high or low toxin titres, or in the presence or absence of rectal pseudomembrane raises the possibility that the changeso observed may be more closely related to other믈 underlying disorders than to AAC. Conversely, any $\frac{\bar{c}}{5}$. real changes in these measurements arising from ${ }_{\propto}^{\mathbb{\Phi}}$ AAC may have been masked by the effect of thes underlying disease. Many of the patients studied. had had surgery, often for malignant disease, and $\stackrel{\circ}{-}$ some cases were complicated by wound infection. $\vec{\omega}$ Therefore the part played by AAC in causing the observed changes in white cell count, temperature and albumin and orosomucoid concentrations is notiw clear.

Perhaps the most intriguing finding was the signi-ir ficant relation between exposure to clindamycin oro lincomycin and a high faecal toxin titre. This com-윽 parison was made because in vitro experiments haveshown that $\mathrm{Cl}$ difficile produces the most toxin when grown in the presence of clindamycin or linco $\approx$ mycin. ${ }^{9}$ Toxin production was not enhanced by $\overrightarrow{0}$ penicillins, cephalosporins, aminoglycosides, tetra- $-\stackrel{\infty}{-}$ cycline, vancomycin, or bacitracin. At first sight this finding would support the widely-held belief that clindamycin and lincomycin predispose to a more severe form of AAC than other antibiotics. However, the incidence of rectal pseudomembrane was not significantly greater in the clindamycin- or lincomycin-treated patients. We believe that the amounto of toxin measurable in faeces is not the major determinant for the formation of pseudomembrane The duration of exposure to $\mathrm{Cl}$ difficile toxin may be the primary factor in determining the outcome, and production of toxin by clostridia adhering to the mucosa may also be important.

We conclude that the detection in faeces of the्ठ toxin produced by $\mathrm{Cl}$ difficile is a useful method for the diagnosis of AAC, but that determination of theo toxin titre does not provide additional useful infor mation. Histological evidence of pseudomembrane? in a rectal biopsy is of value in identifying those patients with extensive pseudomembranous changes, and with a more serious prognosis.

\section{References}

1 Bartlett JG, Chang TW, Gurwith M, Gorbach SLC Onderdonk AA. Antibiotic associated pseudomembra:nous colitis due to toxin-producing clostridia. $N$ Engl गु Med 1978;298:531-4.

2 George RH, Symonds JM, Dimock F, et al. Identification of Clostridium difficile as a cause of pseudomembranous colitis. Br Med J 1978; ; 695.

${ }^{3}$ Tedesco FJ. Antibiotic associated pseudomembranouছ colitis with negative proctosigmoidoscopy examination Gastroenterology 1979;77:295-7. 
4 George RH. A micro-method for detecting toxins in pseudomembranous colitis. J Clin Pathol 1979;32:303-4.

5 Price AB, Davies DR. Pseudomembranous colitis. J Clin Pathol 1977;30:1-12.

- Keighley MRB, Burdon DW, Arabi Y, et al. Randomised controlled trial of vancomycin for pseudomembranous colitis and postoperative diarrhoea. $\mathrm{Br}$ Med $J$ 1978; ii : 1667-9.

7 Pashby NL, Bolton RP, Sherriff RJ. Oral metronidazole in Clostridium difficile colitis. Br Med J 1979;i:1605-6.

${ }^{8}$ Mogg GAG, Keighley MRB, Burdon DW, et al. Antibiotic-associated colitis-a review of 66 cases. Br J Surg
$1979 ; 66: 738-42$.

${ }^{9}$ George RH, Johnson M, Youngs D, Burdon DW. Induction of Clostridium difficile toxin by antibiotics. Proceedings 11th international congress of chemotherapy and 19 th interscience conference on antimicrobial agents and chemotherapy, 1979:955-6.

Requests for reprints to: Dr DW Burdon, Microbiology Department, The General Hospital, Steelhouse Lane, Birmingham B4 6NH, England. 